\title{
Musiikki, ääni ja hyvinvointi -symposium
} 9.-10.9.2021 Itä-Suomen yliopisto, UEF, Joensun

FT Noora Vikman (noora.vikman@uef.fi) työskentelee yliopistonlehtorina Itä-Suomen yliopistossa ja on vastuussa etnomusikologian erikoistumisalan perus- ja aineopinnoista. Opetustyön ohella hän on vetänyt ja osallistunut ääniympäristötutkimukseen liittyviin, aktiivista osallistavaa kuuntelua, luonnon äänimaisemia, kestävää matkailua ja hiljaisuutta pohtiviin ja soveltaviin projekteihin. Tämän numeron julkaisuhetkellä hän on puolen vuoden tutkimusvapaalla Koneen sä̈̈tiön rahoittamassa Suotrendi-hankkeessa. 


\title{
Musiikki, ääni ja hyvinvointi -symposium 9.-10.9.2021 Itä-Suomen yliopisto, UEF, Joensuu
}

\author{
Noora Vikman
}

Musiikki, ääni ja hyvinvointi -symposium on eri tieteenalojen tutkijoiden sekä taiteen ja hyvinvointialan toimijoiden kohtaamispaikka, joka järjestettiin ensimmäisen kerran Joensuussa syyskuussa 2019. Tarkoitus on tarjota foorumi äänen vaikutuksista ja tutkimustulosten soveltamisesta kiinnostuneiden ja hyvinvointipalvelujen parissa toimivien ammattilaisten ajatustenvaihdolle sekä luoda ymmärrystä kokonaisvaltaisemman hyvinvoinnin aspekteista. Symposiumissa kulttuurisia merkityksiä ja koettua hyvinvointia on tuotu esiin monitieteisessä kontekstissa. Kulttuurin ja äänimaiseman tutkimus laajentaa ymmärrystä hyvinvoinnin edistämisestä kehollisena ja ympäristöön liittyvänä kokemuksena.

Vuonna 2021 symposium päätettiin järjestää online-tapahtumana virtuaalisen kohtaamisen haasteista huolimatta. Siinä painotettiin ympäristön äänten suhdetta hyvinvointiin. Ohjelma haluttiin rakentaa siten, että se tukisi parhaiten tiedon ja kokemusten kiireetöntä vaihtoa ja että kaikilla olisi mahdollisuus seurata kaikkia sessioita ja pysyä mukana kumuloituvassa keskustelussa. Siksi rinnakkaisia esitelmäsessioita ja työpajoja ei ollut kuten vuonna 2019. Kaiken kaikkiaan osallistujia oli yli sata, ja jokaiseen sessioon osallistui seitsemisenkymmentä kuulijaa. Palautteen mukaan Tuomas Partasen teknisesti fasilitoima konsepti vastasi tiedon ja kokemusten jakamisen tarpeeseen.

\section{Yhdessä kuunteleminen}

Symposiumin avasi elokuvatutkija, taiteilijanakin tunnettu Budhaditya Chattopadhyay, joka esitteli keynote-luennossaan "Hyper- and Co-listening: Thoughts on Sound, Selfhood, Solidarity, and Solace" osallistavien metodien periaatteitaan. Meditatiivisen hyperlistening ja ympäristön äänimaailmaa 
todistavan ja yhdessä koetun co-listening-metodien tarkoitus on herkistää ja ohjata osallistujaa itsen ja ympäristön välisen suhteen tarkkaan havainnointiin. Ideaalin mukaan oman itsen kuuntelun ja tietoisuuden laajentumisen jälkeen ympäristön kuuntelu voi synnyttää sulautumisen kokemuksia. Kun ympäristö resonoi ihmisen kehossa myös ymmärrykselle erilaisia ihmisiä ja näkökulmia kohtaan, hyvinvoinnin toteutumisille avautuu suurempi mahdollisuus. Ympäristön havainnoinnin ja taiteellisen työskentelyn välineinä on aiemmin hyödynnetty muun muassa kausaalisen, semanttisen ja pelkistetyn kuuntelun metodeja. Esitelmässään Chattopadhyay esitteli holistisen syväkuuntelun metodin, jota on käytetty muiden muassa sävellystyön työkaluna. Teoksissaan The Nomadic Listener (2020) ja The Auditory Setting (2021) Chattopadhyay vertailee käyttämiään lähtökohtia aiempiin käsityksiin kuuntelemisen erilaisista tavoista.

Paneelikeskusteluissa luotiin katsaus kahteen kokonaisvaltaisvaltaisemman hyvinvoinnin tutkimusalueeseen. Yleisöllä oli mahdollisuus osallistua esitelmien välissä myös kahteen kokemuksellisempia elementtejä sisältävään työpajaan: Peter Appelin Movingness-liikemetodiin sekä Petri Berndtsonin ja Saara-Maija Strandmanin keskustelevaan, tietoisen hengittämisen filosofiaan.

\section{Traditio ja kuuntelu}

Symposiumin ensimmäisen tutkimusesitelmäsession avasi Riitta Rainion ja Noora Vikmanin esittely yhteisestä tutkimuksestaan "Engagements with environment - art of echos, traditions and rituals". Sen lähtökohtana on kysymys, miten erilaiset kuulijat ovat luoneet ja luovat edelleen käsityksiä paikasta. Erilaiset luonnonympäristöt - suot, kalliot, metsät - kaiuttavat ääntä eri tavoin ja luovat erityistä paikan tuntua. Niiden perusteella esimerkiksi kansanparannuksen perinteissä akustisista ominaisuuksista on haettu parantamiseen, ihmisen ja muun luonnon väliseen tasapainoon ja kokonaisvaltaiseen hyvinvointiin tarvittavaa syntytietoa. Kiinnostava näkökulma ihmisen ympäristösuhteen tutkimiseen on, miten aiempien parannustraditioiden tunteminen vaikuttaa yhä luonnon havainnointiin ja kuuntelemiseen.

Elina Hytönen-Ng esitteli symposiumissa äänellä itkemisen perinteen kehollista kokemusta otsikolla "Corporeal experience of lamenting creating wellbeing". Äänellä itkijöiden haastatteluihin perustuvissa huomioissa mainittiin muiden muassa, kuinka itkiessä kehosta koettiin vapautuvan surua. Surun saattoi tuntea kehossa konkreettisena hyperventilaationa tai 
vatsa-ja kylkikramppeina. Kumartunut asento tuki äänellä itkemistä. Itkijät kokivat surun olevan ylisukupolvista. Itkeminen loi yhteyden menneisiin sukupolviin ja tässä tapauksessa Karjalaan.

Soile Päivikki Hämäläinen kertoi työstään, jossa joikaamista ja hoitotyötä on yhdistetty saamelaisten dementiapotilaiden parissa. Saamelaisille joikaaminen on tapa olla maailmassa ja yhteydessä ympäristöönsä sekä mahdollisuus ilmaista itseään osana yhteisönsä perintöä.

Hyvinvointivaikutusten tutkimuksen viitekehyksessä tutkimus osoitti, kuinka joikaamisella voi olla virkistävä ja muistoja aktivoiva vaikutus saamelaisiin dementiapotilaisiin. Siten joikaaminen voi olla hoitotyötä tukeva menetelmä. Esitelmässä korostui ajankohtaiseksi noussut kysymys kulttuuristen perinteiden akateemisen tutkimisen hienovaraisuuden ja sensitiivisyyden tarpeesta.

\section{Kulttuurinen hyvinvointi}

Paneelikeskustelu avasi symposiumin toisen päivän. Äänessä olivat Pia Hounin johdolla taiteen ja hyvinvoinnin käytäntöjen asiantuntijat. Pauliina Lapio toimii tuottajana ja luo taiteilijoiden ja terveydenhuollon instituutioiden välisiä kohtaamisia. Lapion avauspuheenvuorossa kuultiin jyväskyläläisestä Sairaala Novasta, jossa on tehty merkittävä yhteistyön avaus kutsumalla taiteilijoita työskentelemään sairaalan tiloissa. Sairaala Novan toiminta on esimerkki siitä, kuinka suuressa instituutiossa on tunnistettu taiteen arvo sekä potilaiden että hoitohenkilökunnan hyvinvoinnin edistäjänä.

Taru Tähti on tutkinut musiikin hyvinvointivaikutuksia vanhustyössä. Väitöskirjatyönsä perusteella hän on eritellyt laulamisen hyvinvointivaikutuksia ja vanhustyöhön osallistuvien toimijuuden osa-alueita, jotka ulottuvat esteettisen, emotionaalisen, kehollisuuden, oppimiseen, identiteetin ilmaisun sekä organisaation kehittymisen alueille. Se tarjoaa yhden hyödylliseksi koetun mallin ja välineen taiteen hyvinvointivaikutusten jäsentämiseen sekä käytännön työn järjestämiseen. Merja Pennanen kertoi työskentelystään Kulttuurista hyvinvointia Pohjois-Karjalaan -hankkeessa, jossa edistetään kaikkien tasavertaista oikeutta ja pääsyä taiteen äärelle.

Keskustelussa nostettiin esiin myös taiteen kentälle tuttu "hyvinvointitaiteen" ja "oikean taiteen" välinen hierarkia ja monikerroksinen suhde. Eräs symposiumin yhteydessä järjestetylle Musiikki, ääni ja hyvinvointi -kurssille osallistunut opiskelija hahmotti suhdettaan taiteen rooliin luentopäiväkirjassaan seuraavasti: "Taiteen rahoituksen lisäämistä pohdittaessa on oleellista tarkastella taiteen arvoa erilaisten mittareiden avulla ja samalla 
muistaa se, että taiteen luonteenomainen piirre on sen 'hyödyttömyys' sekä se, ettei taiteellinen työskentely perustu välttämättä hyödyn tavoitteluun. Esimerkkejä sekä 'hyvinvointitaiteen' että 'oikean taiteen' parissa ansioituneesti työskentelevistä taiteilijoista on kuitenkin monia. Tällaisena nostan esiin parhaiten tuntemaltani tanssitaiteen kentältä arvostetun nykytaiteen tekijän ja koreografin Liisa Pentin, joka on työskennellyt pitkäjänteisesti autististen nuorten parissa."

\section{Ä̈̈ni ja terapia}

Seuraavassa Ida-Meri Havukaisen fasilitoimassa sessiossa, joka keskittyi äänen ja terapian suhteeseen, saatiin kuulla konkreettisia esimerkkejä suomalaisen hyvinvointitoiminnan kentältä. Espoon sairaalan musiikkiterapeutti Sari Laitinen kertoi käyttämistään metodeista ja musiikkiterapian mahdollisuuksista osana aivohalvauspotilaiden hoitoon keskittyvää hanketta.

Espoossa dysfasiapotilaille järjestetyn puutarhakonsertin aikana yhteisömuusikko loi laulun osallistujilta poimituista aiheista ja sanoista, ja laulua laulettiin yhdessä työpajan jälkeenkin. Toisessa työpajassa musisointi kehollistui toiminnallisesti, kun kaikki osallistujat loivat yhteistä äänimaisemaa soittamalla yhtä instrumenttia. Kolmas songdrawing-metodi yhdisti kehon ja äänen kokemuksen. Osallistujan käsi piirsi vetäjien säestämiä ja soittamia lauluja paperille ja teki samanaikaisesti näkyväksi mitä laulettiin.

Tutkija ja kuoronjohtaja Eija-Liisa Sokka-Meaney esitteli tuloksia kuorolaulun vaikutuksista terveyteen ja hyvinvointiin kolmen kyselynsä perusteella. Ilmi tulleita kehollisia tuntemuksia olivat surullisuus, tylsyys, lihasjäykkyys, henkinen stressi ja halu liikkua yhdessä laulun ohella. Säännöllinen ja toistuva yhdessä tekeminen ja sosiaaliset kontaktit mainittiin tärkeiksi. Tämä ilmeni esimerkiksi sen perusteella, miten kuorolaiset kokivat muiden muassa koronatauon vaikuttaneen tuntemuksiinsa. Vuonna 2021 tehdyssä tutkimuksessa kävi ilmi, että enemmistö vastanneista koki tulleensa aktiivisemmaksi muillakin elämänalueilla kuorolaulun johdosta. Kuorossa laulaminen on erityisesti tärkeää sosiaalisten suhteiden kannalta, ja niinpä joku koki tulleensa pandemian aiheuttaneen kuorolaulutauon aikana passiiviseksi. Esitelmän jälkeen saatiin taustatietoa musiikin vaikutuksesta aivojen kuntoutumiseen, ja kuulijat pääsivät jakamaan kokemuksiaan laulamisen sekä kuoronjohtamisen haastavuudesta koronarajoitusten aikana.

Musiikin tohtori, laulupedagogi Hilkka-Liisa Vuori ja laulaja, toimittaja Johanna Korhonen raportoivat vasta alkaneesta kahden vuoden pituisesta projektistaan, jolle Uudenmaan liitto oli myöntänyt rahoituksen. Projektin 
tarkoitus on tutkia, kuinka olisi mahdollista järjestää hyvinvointipalveluja yhtä helposti kuin ostaisi siivouspalveluja. Korhonen ja Vuori työskentelevät hankkeessa hoitohenkilöstön rinnalla: laulaen sen mukana arjen tilanteissa sekä toisaalta ohjaamalla hoitajia käyttämään laulua työssään. Työskentelytapa nähtiin kiinnostavana ja arvokkaana tapana jakaa taiteilijuutta työvälineeksi toisen ammattikunnan käyttöön.

Tässä hankkeessa toimijat jalkautuvat hoitoyksiköihin, joissa he osallistuvat jokapäiväisten käytännön haasteiden ratkomiseen. Hankkeessa arkilauluksi kutsuttua työskentelytapaa hyödynnetään muistisairaiden hoivatyön haasteellisissa arjen toiminnoissa. Esimerkiksi peseytymisestä tai vessassa käymisestä pyritään tekemään sekä hoitajalle että potilaalle miellyttävämpää esimerkiksi potilaan nimeä kevyesti laulaen tai hyräillen. Lähtökohtana on kannustaa sekä hoitajaa että hoidettavaa löytämään motivaatio kuulla ja kuunnella toinen toistensa ääniä.

Symposium päättyi Noora Vikmanin vetämään paneelikeskusteluun immersiivisestä äänestä. Paneelikeskustelussa pohdittiin, mitä mahdollisuuksia ja tavoitteita ihmisymmärrykseen perustuvien sekä teknologian avulla luotavien tilojen luomiseen liittyy. Keskustelijoina paneelissa olivat äänisuunnittelun ja musiikin ammattilaiset Michael Böger, Budhaditya Chattopadhyay, Antti Ikonen ja Markus Pesonen.

Yhtenä paneelikeskustelun teemana oli pohtia taiteilijan vastuuta äänentuottamisen turvallisuudesta. Usein immersiivisen konseptin tavoitteena on luoda luottamuksellinen tila, jossa henkilökohtaisia kokemuksia voi jakaa ryhmään osallistuneiden kesken. Immersiivisen äänen kokemusta havainnollistettiin keskustelussa vertaamalla kuuloalueen laajuutta näkökentän kapealaisuuteen: "kuin olisi silmät selässäkin". Immersiivistä ääniteknologiaa kehitetään toden tunnun tuottamiseksi. Sellaisena kokemusta jäljittelevä tuotettu äänimaisema voi yllättää kokijansa, luoda voimakkaita kehollisia kokemuksia ja aiheuttaa kokijassa epätoivottujakin reaktioita. Joku kommentoijista ehdotti immersiivisyyden vetoavan modernin keskiluokkaisen elämäntavan reaktiivisen jännityksen tarpeeseen. Toinen mahdollinen immersiivisyyden elämyksen tuottajien/hyödyntäjien tavoite on tarjota toisinkuulemisen ja vastarinnan paikkoja, jotka jättävät tilaa myös omaehtoisemmille tulkinnoille.

Antti Ikonen esitteli keskustelussa projektiaan Helsingin Uuden lastensairaalan tilojen äänisuunnittelijana. Siinä missä kuluttaja yleensä päättää itse osallisuutensa, eivät esimerkiksi lastensairaalan työntekijät tai potilaat voi valita, millaiselle pitkäkestoiselle sairaalataiteelle he altistuvat päivittäin. Tämä on pyritty ottamaan huomioon sairaalan äänimaiseman suunnittelussa. Keskustelun yhteydessä puhuttiin myös yleisemmin äänelle altistumises- 
ta erilaisissa ympäristössä sekä vastuusta julkisten ja puolijulkisten tilojen äänimaisemien muokkaamisesta.

\section{Kysymyksiä tulevaisuudelle}

Symposium kutsui koolle musiikin, kuuntelun, äänen ja ääniympäristöjen tutkimuksen sekä käytäntöjen parissa toimivia ammattilaisia. Sen aikana on ollut mahdollisuus kuulla kiinnostavaa vertailua siitä, miten äänen kehollisuuden pohtiminen musiikkiterapian ja -kasvatuksen piirissä on integroitunut eri yhteiskuntien hyvinvointipalveluihin. Kulttuurihyvinvoinnin konkreettisten projektien toteuttamisessa tarvitaan tavoitteellista, monialaista ja pitkäjänteistä yhteistyötä eri toimijoiden välillä. Kuten muutkin monialaiset yhteistyöprojektit, ne kaipaavat selkeää ymmärrystä osaamisalueista sekä sopimuksia ja roolijakoja. Projektien tapaustutkimusten kuvaukset antoivat eväitä taiteilijan ja tilaajan välisen yhteistyön suunnittelemiseksi. Onko äänen tutkimus kansainvälisestikin laajentumassa alueeksi, jossa halutaan korostaa sekä ääniympäristön laadun että keskittymisen, rauhoittumisen itsetuntemuksen merkitystä hyvinvoinnin lähteinä? Miten toimijat ja toiminnot ovat integroituneet yhteiskunnan hyvinvointipalveluihin ja miten tieto kulkeutuu taide-ja ympäristöalojen kehittämisen tarpeisiin? Tutkitun uuden tiedon soveltaminen käytännön projekteihin ja sen tiedon raportoiminen voi olla käytännössä hedelmällinen tutustumisen kehä.

Symposiumin tarkoitus oli myös kannustaa ja innostaa mukaan uusia toimijoita, joita työskentely saattaa kiinnostaa sekä antaa opiskelijoille vihiä projektivaltaisen työelämän mahdollisuuksista. Esimerkiksi Pohjois-Karjalassa viranomaiset ovat osoittaneet kiinnostusta yhteistyöhön ja ilmaisseet, kuinka "hyvinvointisektorin asiakkaat ovat kyltymättömiä kulttuurin suhteen".

Sekä vuoden 2021 että vuoden 2019 symposiumien esitelmien ja työpajojen abstraktit on luettavissa symposiumin nettisivuilta näistä linkeistä: https://sites.uef.fi/musicsoundwellbeing/program/, https://sites.uef.fi/musicsoundwellbeing/abstracts/ja https://sites.uef.fi/musicsoundwellbeing/abstracts-2019/. 